\title{
Yeast 3-Hydroxy-3-methylglutaryl-CoA Reductase: an Enzyme Committed to Catabolite Derepression Before Exhaustion of Fermentable Substrate
}

\author{
By D. E. QUAIN*† AND J. M. HASLAM \\ Department of Biochemistry, University of Liverpool, P.O. Box 147, Liverpool L69 3BX, U.K.
}

(Received 25 November 1981; revised 9 March 1982)

\begin{abstract}
Saccharomyces cerevisiae grown on glucose $(1 \%, w / v)$ medium exhibited diauxic growth because of the transition from catabolite-repressed fermentative metabolism to derepressed oxidative metabolism. 3-Hydroxy-3-methylglutaryl-CoA reductase (HMG-CoA reductase; EC 1 1 1 1 1 34) was subject to catabolite repression and required cytoplasmic protein synthesis for derepression. The addition of glucose $(2 \%, \mathrm{w} / \mathrm{v})$ at up to $4 \mathrm{~h}$ prior to glucose exhaustion had no effect on subsequent derepression of $\mathrm{HMG}-\mathrm{CoA}$ reductase, suggesting that the enzyme was irreversibly committed to derepression at this stage. However, other derepressible enzyme activities such as NAD-dependent glutamate dehydrogenase (EC 1.4.1.2) and malate dehydrogenase (EC 1.1.1.37) did not show a commitment to derepression at this time. In contrast, NADPdependent glutamate dehydrogenase (EC 1.4.1.4) was induced by the addition of glucose.
\end{abstract}

\section{INTRODUCTION}

The metabolism by Saccharomyces cerevisiae of rapidly fermentable sugars, such as glucose, results in aerobic glycolysis and the repression of respiration. This catabolite repression is characterized by the inhibition of synthesis of respiratory enzymes and of components involved in the biogenesis of mitochondria. Catabolite derepression occurs after the fermentable sugar is exhausted, or if the cells are grown on a non-fermentable carbon source, and is typified by the presence of fully functional mitochondria supporting oxidative metabolism (for a review see Linnane \& Haslam, 1970).

Cells growing on a medium containing low concentrations of glucose $(1 \%$ w/v) exhibit diauxic behaviour with respect to growth and physiology. This cultural regime has provided a convenient system for the study of the transition between catabolite-repressed and catabolitederepressed states (Polakis \& Bartley, 1965; Perlman \& Mahler, 1974; Quain \& Haslam, $1979 a, b)$. However, complete exhaustion of glucose is not necessarily a prerequisite for the catabolite derepression of all affected enzymes, because in Schizosaccharomyces pombe derepression of respiratory enzyme activities occurs at a glucose concentration of $0.2 \%(\mathrm{w} / \mathrm{v})$ (Poole \& Lloyd, 1973). Furthermore, Perlman \& Mahler (1974) distinguished two phases of catabolite derepression during diauxic growth. The 'fermentative phase' of derepression was characterized by the derepression of enzyme activities before the external glucose concentration fell below $0.4 \%(w / v)$. Only mitochondrial respiratory chain activities, such as cytochrome oxidase, failed to be derepressed unless the external glucose concentration fell below $0 \cdot 1 \%(\mathrm{w} / \mathrm{v})$, and this is referred to as the 'oxidative phase' of derepression. Perlman \& Mahler (1974) also showed that the fermentative phase of catabolite derepression did not require mitochondrial protein or RNA synthesis and was unaffected by the presence of the respiratory chain inhibitor, antimycin $\mathrm{A}$; in contrast, the oxidative phase of derepression required all of these mitochondrial functions.

The effects of the addition of glucose to catabolite-derepressed cultures have been investig-

$\dagger$ Present address: Bass Research Laboratory, Bass Brewing Limited, High Street, Burton-on-Trent DE14 $1 \mathrm{JZ}, \mathbf{U} . \mathbf{K}$. 
ated in studies of catabolite inactivation (for a review see Holzer, 1976) and in studies of the mechanism of catabolite repression (Zitomer \& Nichols, 1978; Zitomer et al., 1979). However, little attention has been directed towards the study of the effects of the addition of glucose prior to, or during, catabolite derepression. Chandrasekaran et al. (1978) have shown that the addition of glucose at the start, or in the early stages, of catabolite derepression resulted in the immediate repression of respiration and components dependent on mitochondrial protein synthesis. The effects of glucose addition on the formation of the products of cytoplasmic protein synthesis differed; for a limited period, such components increased in activity even relative to catabolitederepressing control cultures run in parallel but, after a few hours, addition of glucose resulted in repression.

We investigated changes in the specific activities of 3-hydroxy-3-methylglutaryl-CoA reductase (HMG-CoA reductase, EC 1.1.1.34), NAD-dependent glutamate dehydrogenase (NAD-GDH, EC 1.4.1.2), NADP-dependent glutamate dehydrogenase (NADP-GDH, EC 1.4.1.4) and malate dehydrogenase (MDH, EC 1.1.1.37) during and just after the exhaustion of glucose in the medium, and compared the effects of adding a high glucose concentration $(2 \%$, $\mathrm{w} / \mathrm{v}$ ) prior to glucose exhaustion on the ensuing activities of the enzymes in test and control cultures. The four enzymes studied have different responses to the presence of glucose. In yeast there are two isoenzymes of MDH, one is located in the mitochondria and the other is cytoplasmic (van Rijn \& van Wijk, 1972). The mitochondrial form is subject to catabolite repression (van Rijn \& van Wijk, 1972) whereas the cytoplasmic isoenzyme is susceptible to rapid catabolite inactivation by glucose (for a review see Holzer, 1976). The catabolic NAD-GDH is subject to catabolite-repression (Beck \& Meyenberg, 1968; Nuñez de Castro et al., 1970; Perlman \& Mahler, 1974; Mahler et al., 1975), whereas the anabolic NADP-GDH is induced by glucose (Polakis \& Bartley, 1965) and was measured as a control in these studies. Quain \& Haslam (1979a) showed that HMG-CoA reductase is also subject to catabolite repression.

\section{METHODS}

Yeast strain. Strain AB1 of $S$. cerevisiae was supplied by Allied Breweries (Production), Burton-on-Trent, and maintained as described previously (Quain \& Haslam, 1979a).

Sampling and preparation of cell-free extracts. Yeast $\left(10 \mu \mathrm{g}\right.$ dry $\left.\mathrm{wt} \mathrm{ml}^{-1}\right)$ was inoculated into six $1 \mathrm{l}$ cultures containing glucose $(1 \%, \mathrm{w} / \mathrm{v})$ and grown aerobically at $30^{\circ} \mathrm{C}$ on a rotary shaker $(180$ r.p.m.). After $10 \mathrm{~h}$ of growth, $650 \mathrm{ml}$ of culture was removed from a shake flask, harvested and the cells homogenized in a Braun homogenizer as described by Quain \& Haslam $(1979 a$ ). Glucose (equivalent to $2 \%$ w/v) was added to the remaining $350 \mathrm{ml}$ of culture. This process was repeated at $1 \mathrm{~h}$ intervals with four separate cultures. After $17 \mathrm{~h}$ growth, all cultures, including a control culture without glucose addition, were harvested and cell extracts prepared. In the control culture glucose was exhausted from the medium after $14 \mathrm{~h}$ of growth.

The involvement of protein synthesis in the derepression of HMG-CoA reductase was investigated by adding inhibitors to single 11 diauxic cultures (Quain \& Haslam, 1979a,b) at the point of glucose exhaustion. The additions, dissolved in ethanol $(7 \mathrm{ml})$, were cycloheximide $\left(50 \mu \mathrm{g} \mathrm{ml}^{-1}\right)$, erythromycin $\left(1 \mathrm{mg} \mathrm{ml}^{-1}\right)$ and both cycloheximide and erythromycin (at $50 \mu \mathrm{g} \mathrm{ml}^{-1}$ and $1 \mathrm{mg} \mathrm{ml}^{-1}$, respectively). Two control cultures were established, one without any addition and one plus ethanol $(7 \mathrm{ml})$. Cells were harvested after 0,3 and $7 \mathrm{~h}$ of catabolite derepression; cell-free extracts were prepared and specific activities of 3-hydroxy-3-methylglutaryl-CoA reductase were determined.

Enzyme assays. The homogenates prepared as described above were centrifuged at $8000 \mathrm{~g}$ for $10 \mathrm{~min}$, incubated with Triton X-100 $(0.5 \%, \mathrm{v} / \mathrm{v})$ and stored at $-17^{\circ} \mathrm{C}$ as described previously (Quain \& Haslam, 1979a). Cell extracts were thawed once only prior to enzyme assay.

HMG-CoA reductase activity was assayed as described by Quain \& Haslam (1979a). MDH was assayed in the presence of $0 \cdot 1 \%(\mathrm{v} / \mathrm{v})$ Triton X-100 according to the method of Vary et al. (1969); no attempt was made to distinguish between mitochondrial and cytoplasmic forms of the enzyme. NAD-GDH and NADP-GDH were determined as described by Mazon (1978). All assays were in triplicate. Endogenous oxidation of nicotinamide nucleotides was corrected by initiating, in parallel, a control incubation lacking substrate.

Preliminary experiments established that HMG-CoA reductase and MDH increased in activity by $200 \%$ and $50 \%$, respectively, after $8 \mathrm{~h}$ incubation in the derepression system of Mahler et al. (1975).

The present study was conducted during the final stages of glucose $(1 \%, w / v)$ exhaustion $(10$ to $14 \mathrm{~h})$ and up to the time at which growth on ethanol recommenced $(17 \mathrm{~h})$. During this period the specific activities of the catabolite-repressed enzymes HMG-CoA reductase, NAD-GDH and MDH more than doubled. After $17 \mathrm{~h}$, the 
Table 1. Comparison of enzyme activities of cells grown on high glucose $(5$ or $10 \%, w / v)$ medium, or for $10 \mathrm{~h}$ on low glucose $(1 \%, w / v)$ medium

The specific activities of $\mathrm{MDH}$ are in $\mu \mathrm{mol} \mathrm{min}^{-1}(\mathrm{mg} \text { protein })^{-1}$, and those of HMG-CoA reductase

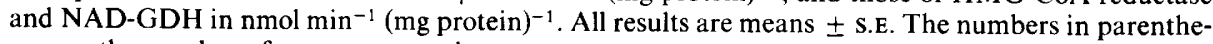
ses are the number of separate experiments.

\begin{tabular}{|c|c|c|c|}
\hline \multirow[b]{2}{*}{ Growth conditions } & \multicolumn{3}{|c|}{ Enzyme specific activities } \\
\hline & MDH & NAD-GDH & $\begin{array}{l}\text { HMG-CoA } \\
\text { reductase }\end{array}$ \\
\hline High glucose medium & $0.67 \pm 0.19(10)$ & $11 \cdot 4 \pm 2 \cdot 0(9)$ & $13 \cdot 5 \pm 2 \cdot 1(9)$ \\
\hline Low glucose medium after $10 \mathrm{~h}$ & $0.86 \pm 0.19(2)$ & $7 \cdot 7 \pm 2.6(2)$ & $10.5 \pm 3.0(2)$ \\
\hline
\end{tabular}

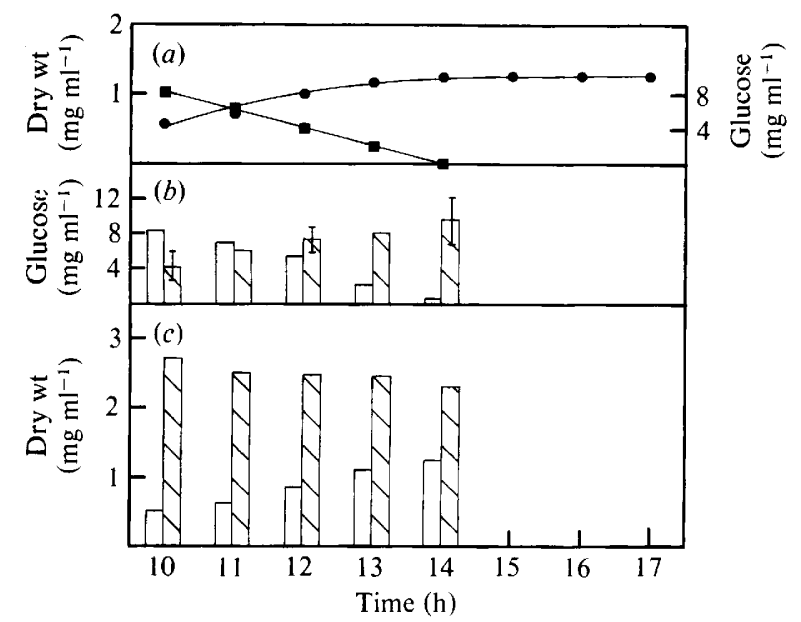

Fig. 1. Changes in dry weight and concentration of glucose following glucose supplementation. (a) Dry biomass $(O)$ and concentration of glucose $(\square)$ in control cultures containing, initially, $1 \%(w / v)$ glucose. The histograms show $(b)$ glucose and $(c)$ biomass concentrations immediately prior to addition of glucose $(2 \% \mathrm{w} / \mathrm{v})$ (open columns) and at the end of the incubation ( $17 \mathrm{~h}$ ) (hatched columns) additional glucose $(2 \%, w / v)$ having been added at the times indicated. The bars indicate the values in two separate experiments; where no error bars are shown, values were identical.

activities of the three enzymes continued to increase, and at $30 \mathrm{~h}$, when the cells were growing exponentially by ethanol oxidation, the specific activity of HMG-CoA reductase was eight times the repressed activity (Quain \& Haslam, 1979a), and extensive increases in the activities of the other enzymes also occurred (for a review see Linnane \& Haslam, 1970). The specific activities of HMG-CoA reductase, MDH and NAD-GDH at $10 \mathrm{~h}$ are similar to the fully repressed values found in cultures growing on high $(5$ or $10 \%, w / v)$ concentrations of glucose (Table 1). Between 10 and 14 h of growth on glucose $(1 \%, w / v)$ medium, the glucose concentration declined to zero. Growth then ceased until $17 \mathrm{~h}$ when oxidative growth commenced (Quain \& Haslam, 1979a). Figure $1(a)$ shows changes in glucose concentration and the growth curve between $10 \mathrm{~h}$ and $17 \mathrm{~h}$.

The addition of glucose $(2 \%, w / v)$ to cultures at hourly intervals in the period $(10-14 \mathrm{~h})$ just prior to the exhaustion of glucose would be expected to result in the continuation of repression. The specific activities of NAD-GDH, NADP-GDH, MDH and HMG-CoA reductase were determined in all cultures after $17 \mathrm{~h}$ of culture growth, including a control incubation. Although enzyme activities continue to increase for up to $30 \mathrm{~h}, 17 \mathrm{~h}$ was chosen as the reference time because the increases are already large and the cells have not yet started to grow oxidatively at this time.

The concentrations of residual glucose in the medium at the point of glucose addition and at the end of the experiment are presented in Fig. $1(b)$ and growth data for the interval between glucose addition and $17 \mathrm{~h}$ in Fig. $1(c)$. The earlier the addition of glucose, the lower the concentration of glucose at the end of the experiment and the greater the amount of biomass formed.

Other analytical procedures. Cell-free extracts were dialysed against water overnight and protein was 
determined, in the presence of SDS $(0.5 \%, w / v)$, by the Lowry method. Glucose and cell dry weight were determined as described previously (Quain \& Haslam, 1979a). Ammonia was assayed using the phenol/sodium nitroprusside/alkaline sodium hypochlorite procedure (Weatherburn, 1967).

\section{RESULTS}

\section{Effects of glucose addition on changes in enzyme activities during the early stages of catabolite derepression}

The course of derepression and the effects of glucose $(2 \%, \mathrm{w} / \mathrm{v})$ added at times between 10 and $14 \mathrm{~h}$ are shown in Fig. 2. The open histograms show that HMG-CoA reductase and NAD-GDH respectively doubled and trebled in specific activity between 10 and $17 \mathrm{~h}$. MDH activity did not appreciably increase in activity until $14 \mathrm{~h}$, but then doubled between 14 and $17 \mathrm{~h}$. Figure $2(d)$ (open histograms) shows that the specific activity of the anabolic NADP-GDH was not significantly affected by the decreasing glucose concentration.

The hatched histograms represent the specific activities of the enzymes, after different periods of catabolite repression produced by the addition of glucose $(2 \%, \mathrm{w} / \mathrm{v})$. The anabolic and catabolic forms of glutamate dehydrogenase responded to glucose supplementation in opposite ways (Fig. $2 c, d$ ). In agreement with Nuñez de Castro et al. (1970), the anabolic NADP-GDH was induced by glucose addition, exhibiting higher activities than that of the partially derepressed control. In contrast, glucose supplementation prevented the derepression of NAD-
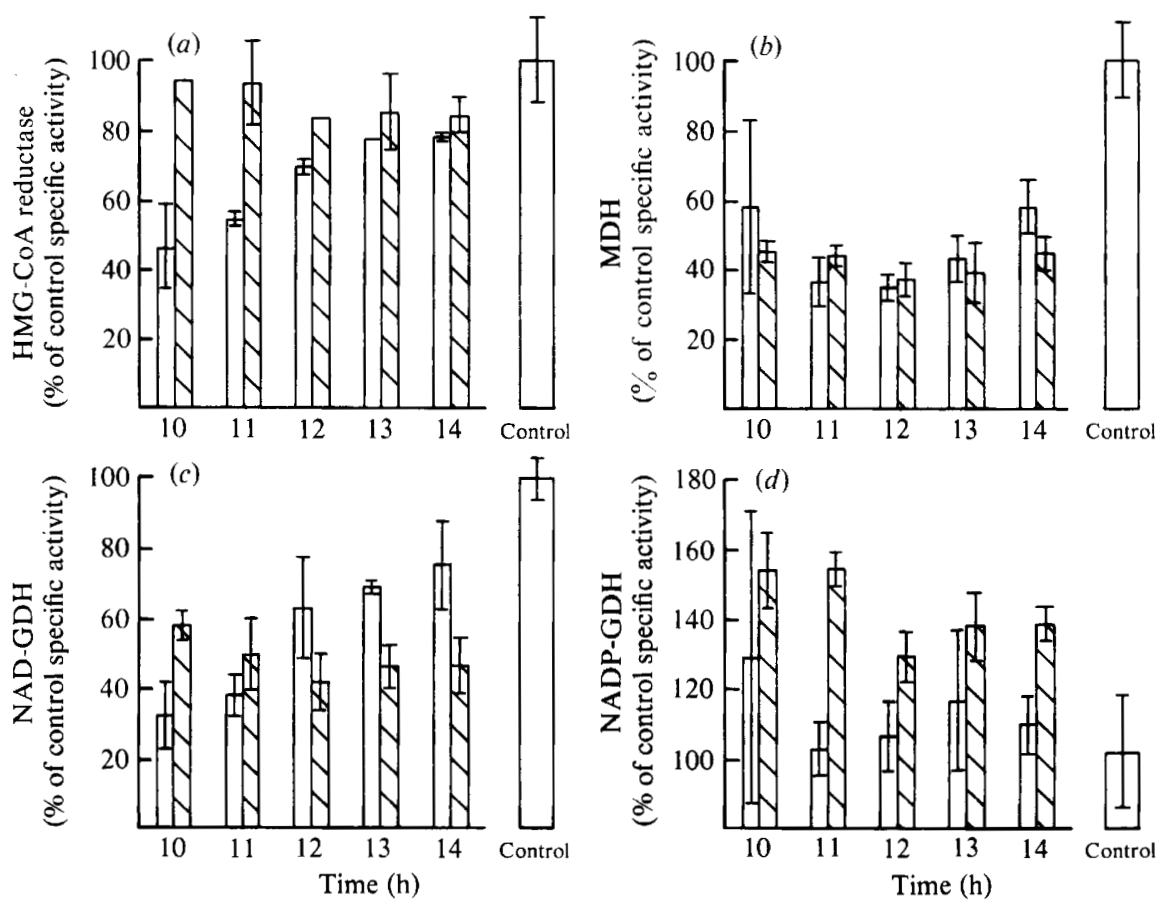

Fig. 2. Effects of glucose supplementation on the catabolite derepression of (a) HMG-CoA reductase, (b) $\mathrm{MDH},(c) \mathrm{NAD}-\mathrm{GDH}$ and $(d) \mathrm{NADP}-\mathrm{GDH}$ activities. Details of incubations and enzyme assays are in Methods. The histograms represent the specific activities of each enzyme as a percentage of that in the control cultures incubated for $17 \mathrm{~h}$. Open columns represent enzyme activities at the times indicated prior to the addition of glucose; hatched columns represent enzyme activities after $17 \mathrm{~h}$ incubation, additional glucose having been added at the times indicated. The specific activities shown are mean values of three assays from two separate experiments; the bars represent S.E.M. Specific activities of the enzymes in the control cultures at $17 \mathrm{~h}$ were: $\mathrm{HMG}-\mathrm{CoA}$ reductase, $23.4 \pm 2.8 \mathrm{nmol}$ $\min ^{-1}(\mathrm{mg} \text { protein })^{-1}$; MDH, $2.69 \pm 0.29 \mu \mathrm{mol} \mathrm{min}^{-1}(\mathrm{mg} \text { protein })^{-1}$; NAD GDH, $23.9 \pm 1.5 \mathrm{nmol}$ $\mathrm{min}^{-1}(\mathrm{mg} \text { protein })^{-1}$; NADP-GDH, $0.54 \pm 0.09 \mu \mathrm{mol} \mathrm{min}^{-1}$ (mg protein $)^{-1}$. 


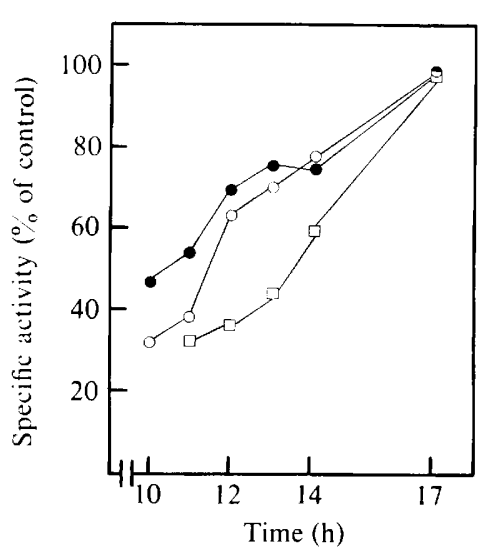

Fig. 3.

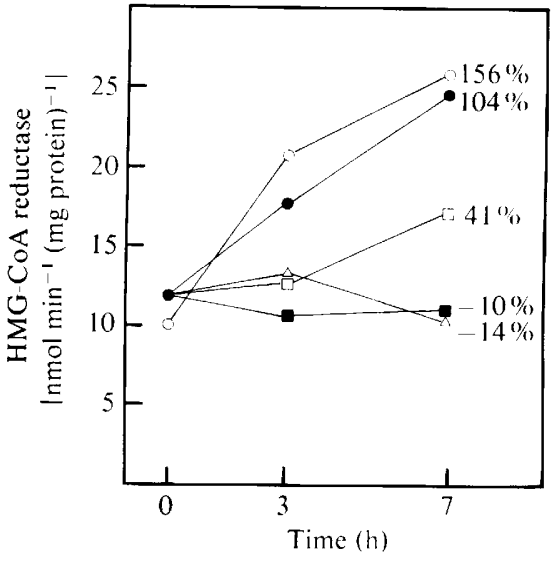

Fig. 4

Fig. 3. Changes in enzyme specific activity during catabolite derepression. Specific activites are expressed as a percentage of the control partially derepressed specific activity at $17 \mathrm{~h}$ (values given in the legend to Fig. 2). O, HMG-CoA reductase; $\square, \mathrm{MDH} ; 0, \mathrm{NAD}-\mathrm{GDH}$. Glucose concentrations in the medium were as in Fig. 1. Results are means of two experiments.

Fig. 4. Effect of inhibitors of cytoplasmic and mitochondrial protein synthesis on the derepression of $\mathrm{HMG}-\mathrm{CoA}$ reductase during growth on glucose $(1 \%, \mathrm{w} / \mathrm{v})$ medium. Incubation procedures and concentration of inhibitors were as described in Methods. Control cultures with $(O)$ and without $(O)$ ethanol $\left(7 \mathrm{ml} \mathrm{l}^{-1}\right)$; cultures containing cycloheximide $(\square)$, erythromycin $(\square)$ and both cycloheximide and erythromycin $(\triangle)$. Inhibitors were added to cultures at the point of glucose exhaustion $(0 \mathrm{~h})$, which was $13-$ $15 \mathrm{~h}$ after inoculation of the cultures. The values adjacent to $7 \mathrm{~h}$ symbols represent the percentage change in specific activity at this time relative to the activity at $0 \mathrm{~h}$.

GDH (Fig. $2 c$, hatched histograms), with the result that the specific activity was typical of catabolite-repressed cells. The observed repression of NAD-GDH was not caused by an increase in the level of ammonium ions, which would strongly repress the activity of the enzyme (Polakis \& Bartley, 1965; Roon \& Even, 1973). Ammonia concentrations were measured: they decreased from 290 to $196 \mu \mathrm{g} \mathrm{ml}^{-1}$ in the control experiment and from 290 to $118 \mu \mathrm{g} \mathrm{ml}^{-1}$ in the experiment where maximum growth occurred [glucose $(2 \%$, w/v) added at $10 \mathrm{~h}$ ].

The addition of glucose during the fermentative phase of derepression maintained the activity of malate dehydrogenase at repressed levels. This suggests that the activities of both cytoplasmic and mitochondrial malate dehydrogenase were unable to increase in the presence of glucose; this agrees with previous observations that derepression of mitochondrial protein synthesis is required for an increase in the activity of mitochondrial malate dehydrogenase, and that the cytoplasmic isoenzyme is inactivated by proteolysis triggered in the presence of glucose (Neeff $e t$ al., 1978).

In contrast to $\mathrm{MDH}$ and NAD-GDH, HMG-CoA reductase activity was not repressed by the addition of glucose prior to the exhaustion of glucose. At the end of the experiment, cultures growing exponentially on the extra glucose exhibited $80-90 \%$ of the $\mathrm{HMG}-\mathrm{CoA}$ reductase activities found in the partially derepressed control cells harvested at the same time. We suggest that $\mathrm{HMG}-\mathrm{CoA}$ reductase is committed to derepression, even when the glucose concentration is as high as $0.8 \%(\mathrm{w} / \mathrm{v})$, and is not repressed by the subsequent addition of a further high concentration of glucose $(2 \%, \mathrm{w} / \mathrm{v})$.

The rates of derepression of $\mathrm{HMG}-\mathrm{CoA}$ reductase, NAD-GDH and MDH were only slightly affected by declining glucose concentration $(<0.8 \%$, w/v $)$ from 10 to $14 \mathrm{~h}$ and after the cessation of growth ( $14 \mathrm{~h}$ to $17 \mathrm{~h}$ ), but the derepression of total MDH occurred rather more slowly than that of the other two enzymes (Fig. 3). The latter observation may be explained by the fact that derepression of the mitochondrial and cytoplasmic malate dehydrogenases occur at different stages. In the presence of glucose the cytoplasmic form of malate dehydrogenase is subject to 
proteolytic degradation (Neeff et al., 1978) and the steeper rise in total activity after $13 \mathrm{~h}$ may represent the extra contribution of this isoenzyme.

\section{Effect of inhibitors of protein synthesis on derepression}

The increase in the activities of all repressible mitochondrial enzymes during derepression is inhibited by cycloheximide; which inhibits cytoplasmic protein synthesis, but is also partly prevented by inhibitors of mitochondrial protein synthesis such as erythromycin, which prevent the development of normal mitochondrial membranes (for review see Linnane \& Haslam, 1970). The derepression of HMG-CoA reductase was completely prevented by cycloheximide (Fig. 4); indeed there was a slight decrease in activity during the $7 \mathrm{~h}$ incubation. Erythromycin initially inhibited the activity of the enzyme, but a significant increase in activity occurred between 3 and $7 \mathrm{~h}$ after the addition of the antibiotic.

\section{DISCUSSION}

Perlman \& Mahler (1974) reported that a number of enzymes, including MDH and NADGDH began their derepression before the external glucose concentration fell below $0 \cdot 4 \%(\mathrm{w} / \mathrm{v})$. Our results agree with this, and show that the same is true of the derepression of HMG-CoA reductase. However, in the strain of $S$. cerevisiae used in the present work, catabolite derepression began with the external glucose concentration fell below about $0 \cdot 8 \%(\mathrm{w} / \mathrm{v})$.

The addition of glucose to catabolite-repressed cells has been shown to prolong the repression of respiration (Chandrasekaran et al., 1978). The present study shows that the addition of glucose to cells prior to the exhaustion of glucose resulted in a return to repression of MDH and NAD-GDH. However, glucose supplementation does not result in repression of HMG-CoA reductase, even when extra glucose $(2 \%, \mathrm{w} / \mathrm{v})$ is added when the residual glucose concentration is as high as $0.84 \%(\mathrm{w} / \mathrm{v})$, and the specific activity at the time is typical of fully cataboliterepressed cultures (Quain \& Haslam, 1979a). We suggest, therefore, that HMG-CoA reductase is fully committed to catabolite derepression well before the glucose is exhausted.

The term 'commitment' has been defined as a physiological point of no return (Mandelstam, 1971). Whether the commitment of $\mathrm{HMG}-\mathrm{CoA}$ reductase to catabolite derepression is a reflection of long-lived mRNA molecules is not known. Certainly, although the half-life of cytochrome $c$ mRNA in $S$. cerevisiae is about $13 \mathrm{~min}$ in both catabolite-repressed and derepressed cells (Zitomer et al., 1979), there is evidence for extremely long-lived mRNA in eukaryotes (Harris, 1974) and for differential rates of mRNA degradation (Stiles et al., 1976).

HMG -CoA reductase, which forms mevalonate from HMG-CoA, appears to be the ratelimiting enzyme in sterol synthesis in yeast (Quain \& Haslam, 1979a; Downing et al., 1980) and in higher eukaryotes (for reviews see Rodwell et al., 1976; Brown \& Rodwell, 1980), where the enzyme is subject to stringent regulation. In rat liver the activity of $\mathrm{HMG}-\mathrm{CoA}$ reductase is regulated by a complex cascade control system involving protein kinases, protein phosphatases and a phosphatase inhibitor protein (Beg et al., 1978; Ingebritsen et al., 1978). An increase in cellular cAMP concentration ultimately causes an increase in the inactive phosphorylated form of the reductase. As yet there is no evidence for a similar system in yeast. Several groups of workers have shown that cAMP reverses catabolite repression of respiration and various mitochondrial enzymes in S. cerevisiae (Fang \& Butow, 1970; Mahler \& Lin, 1978) and there is circumstantial evidence that cAMP is involved in transcriptional control, but the alternative possibility of the modulation of enzyme activity by cAMP also exists. The present observation that cycloheximide inhibits the derepression of $\mathrm{HMG}-\mathrm{CoA}$ reductase shows that a protein is required for the increase in activity. The protein could be the enzyme itself and/or a protein activator of the enzyme. Bard \& Downing (1981) have recently presented genetic evidence for the presence in yeast of an inhibitor of $\mathrm{HMG-CoA}$ reductase which could be one of several of the inhibitory proteins in the scheme of Ingebritsen et al. (1978).

In view of these complexities, it will be necessary to prepare antibodies to the purified reductase and use them to isolate and assay both active and inactive forms of the enzyme in order to determine whether the increase in activity observed during derepression represents 
enzyme synthesis and/or enzyme activation. This and the possible role of cAMP in triggering derepression and maintaining the commitment to derepression of the reductase is under current investigation in our laboratory.

It is hard to explain why yeast $\mathrm{HMG}-\mathrm{CoA}$ reductase should be committed to derepression at a stage when the formation of other mitochondrial enzymes can be reversed. However, the commitment to derepression may reflect the coordination of the synthesis of sterols and other membrane polyisoprenoids derived from mevalonate with cell growth, as has been shown in cultured mammalian cells (for a review see Brown \& Goldstein, 1980). In yeast the oxidative phase of diauxic growth will produce a particular requirement for sterols and ubiquinone in the biosynthesis of mitochondrial membranes plus a general need for sterols in the elaboration of all cell membranes as growth recommences.

D. E. Quain acknowledges SRC CASE award B/76/502208 supported by Allied Breweries (Production), Burton-on-Trent.

\section{REFERENCES}

BARD, M. \& Downing, J. F. (1981). Genetic and biochemical aspects of yeast sterol regulation involving 3-hydroxy-3-methyl-glutaryl coenzyme A reductase. Journal of General Microbiology 125, 415-420.

Beck, C. \& von Meyenburg, H. K. (1968). Enzyme pattern and aerobic growth of Saccharomyces cerevisiae under various degrees of glucose limitation. Journal of Bacteriology 96, 479-486.

Beg, Z. H.. Stonik, J. A. \& BReWer, H. B. (1978). 3Hydroxy-3-methylglutaryl-CoA reductase: regulation of enzymatic activity by phosphorylation and dephosphorylation. Proceedings of the National Academy of Sciences of the United States of America $\mathbf{7 5}$, 3678- 3682

Brown, E. E. \& Rodwell, V. W. (1980). Hydroxymethylglutaryl-CoA reductase. In Dehydrogenase Requiring Nicotinamide Coenzymes, pp. 232-272. Fdited by J. Jeffrey. Basel, Boston \& Stuttgart: Birkhüuser Verlag.

Brown, M. S. \& Goldstein, J. L. (1980). Multivalent feedback regulation of $\mathrm{HMG}-\mathrm{CoA}$ reductase, a control mechanism coordinating isoprenoid synthesis and cell growth. Journal of Lipid Research 21, $505 \div 517$.

Chandrasekaran, K., Murugesh, N.\& Jayaraman, J. (1978). Glucose effect and mitochondriogenesis in yeast. Biochemical and Biophysical Research Communications 82, 693-699.

Downing, J. F., Burrows, L. S. \& Bard, M. (1980). The isolation of two mutants of Saccharomyces cererisiae which demonstrate increased activity of 3hydroxy-3-methylglutaryl coenzyme A reductase. Biochemical and Biophysical Research Communications 94, 974-979.

FANG, M. \& Butow, R. A. (1970). Nucleotide reversal of mitochondrial repression in Saccharomices cerevisiae. Biochemical and Biophysical Research Communications 41, 1579-1583.

Harris, H. (1974). Nucleus and Cytoplasm, 3rd edn. Oxford: Clarendon Press.

Holzer, H. (1976). Catabolite inactivation in yeast. Trends in Biochemical Sciences 1, 178-181.

Ingebritsen, T. S., Lee, H.-S., Parker, R. A. \& Gibson, D. M. (1978). Modulation of activities of both liver microsomal hydroxmethylglutaryl CoA reductase and its inactive enzyme: evidence for regulation by phosphorylation-dephosphorylation.
Biochemical and Biophysical Research Communications 81, 1268-1277.

Linnane, A. W. \& Haslam, J. M. (1970). The biogenesis of mitochondria in Saccharomyces cererisiae. Current Topics in Cellular Regulation 2, 101-172.

MAHLER, H. R. \& Lin, C. C. (1978). Exogenous adenosine $3^{\prime}: 5^{\prime}$-monophosphate can release yeast from catabolite repression. Biochemical and Biophysical Research Communications 83, 1039-1047.

Mahler, H. R., Assimos, K. \& Lin, C. C. (1975). Derepression in Saccharomyces cerevisiae can be dissociated from cellular proliferation and deoxyribonucleic acid synthesis. Journal of Bacteriology 123, 637-641

MandelsTaM, J. (1971). Recurring patterns during development in primitive organisms. Symposia of the Society for Experimental Biology 25, 1-26.

Mazon, M. J. (1978). Effect of glucose starvation on the nicotinamide adenine dinucleotide phosphatedependent glutamate dehydrogenase of yeast. Journal of Bacteriology 133, 780-785.

NeefF, J., Hägele, E., Nauhaus, J., Heer, U. \& MeCKE, D. (1978). Evidence for catabolite degradation in the glucose-dependent inactivation of yeast cytoplasmic malate dehydrogenase. European Journal of Biochemistry 87, 489-495.

Nuñez de Castro, I.. Ugarte, M.. Cano, A. \& MAYOR, F. (1970). Effect of glucose, galactose, and different nitrogen sources on the activity of yeast glutamate dehydrogenase (NAD- and NADPlinked) from normal strain and impaired respiration mutant. European Journal of Biochemistry 16, 567570.

Perlman, P. S. \& Mahler, H. R. (1974). Derepression of mitochondria and their enzymes in yeast: regulatory aspects. Archices of Biochemistry and Biophysics 162, 248-271.

Polakis, E. S. \& Bartley, W. (1965). Changes in the enzyme activities of Saccharomyces cerevisiae during aerobic growth on different carbon sources. Biochemical Journal 97, 284-297.

Poole, R. K. \& Lloyd, D. (1973). Oscillations of enzyme activities during the cell-cycle of a glucoserepressed fission-yeast Schizosaccharomyces pombe $972 \mathrm{~h}^{-}$. Biochemical Journal 136, 195-207.

QuaIn, D. E. \& Haslam, J. M. (1979a). The effects of catabolite derepression on the accumulation of steryl 
esters and activity of $\beta$-hydroxy- $\beta$-methylglutarylCoA reductase in Saccharomyces cerevisiae. Journal of General Microbiology 111, 343-351.

Quain, D. E. \& Haslam, J. M. (1979b). Changes in glucose 6-phosphate and storage carbohydrates during catabolite derepression in Saccharomyces cererisiae. Journal of General Microbiology 113, 195-198.

VAN RIJN, J. \& VAN WIJK, R. (1972). Differential sensitivities of the two malate dehydrogenases and the maltose permease to the effect of glucose in Saccharomyces carlsbergensis. Journal of Bacteriology 110, 477-484.

Rodwell, V. W., Nordstrom, J. L. \& Mitschelen, J. J. (1976). Regulation of HMG-CoA reductase. Adrance's in Lipid Research 14, 2-69.

RoON, R. J. \& Even, H. L. (1973). Regulation of the nicotinamide adenine dinucleotide- and nicotinamide adenine dinucleotide phosphatedependent glutamate dehydrogenases of Saccharomyces cerevisiae. Journal of Bacteriology 116, 367372.
Stiles, C. D., Lee, K. L. \& Kenney, F. T. (1976). Differential degradation of messenger RNAs in mammalian cells. Proceedings of the National Academy of Sciences of the United States of America 73, 2634-2638.

VARY, M. J., EdWARDS, C. L. \& Stewart, P. R. (1969). The biogenesis of mitochondria. IX. Formation of the soluble mitochondrial enzymes malate dehydrogenase and fumarase in Saccharomyces cerevisiae. Archives of Biochemistry and Biophysics 130, 235243.

Weatherburn, M. W. (1967). Phenol hypochlorite reaction for the determination of ammonia. Analytical Chemistry 39, 971-974.

Zitomer, R. S. \& Nichols, D. L. (1978). Kinetics of glucose repression of yeast cytochrome $c$. Journal of Bacteriology 135, 39-44.

Zitomer, R. S., Montgomery, D. L., Nichols, D. L. \& HALL, B. D. (1979). Transcriptional regulation of the yeast cytochrome $c$ gene. Proceedings of the National Academy of Sciences of the United States of America 76, 3627-3631. 